\title{
INFLUENCE OF PREINCUBATION EGG STORAGE DURATION ON EGG QUALITY, HATCHABILITY, EMBRYONIC MORTALITY AND VIABILITY OF DANDARAWI CHICKS
}

\author{
M. El-Sagheer
}

Department of Animal and Poultry Production, Faculty of Agriculture, Assiut University, 71526 Assiut, Egypt

\section{SUMMARY}

The aim of this study was to identify the optimal storage duration of incubated eggs of Dandarawi hens on embryonic mortality, hatchability, one-day chick weight and viability of chicks at 14 days of age. Eggs were collected 4 times daily for 15 consecutive days and stored at $16^{\circ} \mathrm{C}$ and $70 \% \mathrm{RH}$ until sorted into treatments and then were incubated for $21 \mathrm{~d}$ under standard incubation conditions. The 15 experimental groups and control group were as follows: The fresh eggs as control incubated in the same day of lay, while eggs of one to fifteen experimental groups (G1 to G15) were stored from d 1 to 15, respectively. Three replications of 80 eggs per group treatment per incubation setting (total of 3,840 eggs) were studied.

The results showed that, the albumen height, Haugh units and egg yolk index were lower $(P \leq 0.05)$ in

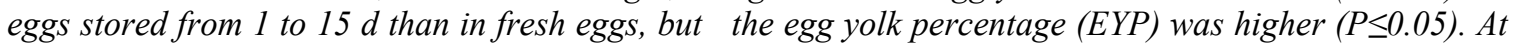
0 to 5 d of storage had no effect on viability of chicks at 14 days of age (VC), but storage periods of more 5 d decreased $(P \leq 0.05)$ VC. Day-old chick weights and chick weights at hatch as percentage of egg weights increased slightly when storage days increased. The hatchability of eggs was lower $(P \leq 0.05)$ with longer periods of storage, but the embryonic morality percentage increased $(P \leq 0.05)$ during the periods from 0 to $6 \mathrm{~d}$ and from 13 to $21 \mathrm{~d}$ of incubation.

Present results suggest that hatchability declines with presetting storage start $1 \mathrm{~d}$ after lay, possibly due to deterioration in egg quality.

\section{Keywords: Eggs storage length, hatchability parameters, viability of chicks}

\section{INTRODUCTION}

Due to variable market demand for 1-d-old chicks in the poultry industry and the maximum hatchery capacity, the total length of egg storage varies between a few days and several weeks. Storage of hatching eggs beyond $7 \mathrm{~d}$ is associated with an increase in incubation duration (Mather and Laughlin, 1976; Tona et al., 2003), a decrease in hatchability (Becker, 1964; Merritt, 1964; Fasenko et al., 2001b; Tona et al., 2004; Yassin et al., 2008), and a decrease in chick quality (Byng and Nash, 1962; Merritt, 1964; Tona et al., 2003, 2004). During egg storage, embryo viability declines, likely due to an increase in cell death (Arora and Kosin, 1968; Bloom et al., 1998). In addition, egg characteristics change due to a loss of $\mathrm{CO}_{2}$ and water from the egg. Albumen $\mathrm{pH}$ increases from about 7.6 to about 9.0 within $4 \mathrm{~d}$ of storage (Lapão et al., 1999). Yolk pH increases from about 6.0 to about 6.5 (Shenstone, 1968), albumen viscosity decreases (Shenstone, 1968; Burley and Vadehra, 1989), and the strength of the yolk membrane decreased as well as during prolonged cold storage (Fromm, 1966; Jones et $a l ., 2002)$. These changes in embryo viability and egg characteristics may be related to the negative effects of prolonged egg storage on hatchability and chick quality (Becker et al., 1968; Meijerhof, 1992; Reijrink et al., 2008).

Increasing the number of storage days increases the proportion of embryonic mortality during storage and incubation and thereby increases the probability of failure to hatch (Whitehead et al., 1985; Yoo and Wientjes, 1991; Scott and Mackenzie, 1993). Influence of the number of storage days before incubation on proportion of embryos that died up to Day 7 of incubation, i.e., early embryonic mortality, and on proportion of embryos that died from Day 8 through Day 22 of incubation, i.e., late embryonic mortality, has been assessed among fertile eggs (Yoo and Wientjes, 1991; Scott and Mackenzie, 1993). Each proportion of early or late embryonic mortality increased at different rates for broiler eggs incubated immediately, compared with those incubated after $7 \mathrm{~d}$ in storage (Scott and Mackenzie, 1993). As the number of days in storage increased from 0 to 20 , the proportion of

Issued by The Egyptian Society of Animal Production 
early embryonic mortality increased in each of two layer lines, but the proportion of late embryonic mortality increased in only one line (Yoo and Wientjes, 1991).

The albumen height of all eggs and Haugh units are at maximum when the egg is laid and decreases with increased storage time (Kahraman-Dogan et al., 1994; Jones et al., 2002). Silversides and Villeneuve (1994) reported that changes in albumen quality during storage are described equally well by albumen height and HU. Stern (1991) reported that, after oviposition, carbon dioxide is released from the egg, resulting in an increase in albumen $\mathrm{pH}$ from about 7.6 to 9.5 within a short period of time, whereas the yolk remains slightly acid, at a $\mathrm{pH}$ around 6.5. Therefore, a 1,000-fold hydrogen ion concentration gradient ( $3 \mathrm{pH}$ units) may exist across the blastoderm. The rise in albumen $\mathrm{pH}$ with storage time and hen age is associated with a decrease in albumen height and viscosity. Albumen liquefaction probably facilitates the movement of nutrients from the albumen to the blastoderm (Brake et al., 1997) and may reduce resistance to gaseous diffusion (Meuer and Baumann, 1988). The extended periods of egg storage allow the albumen to degrade excessively. This degradation causes the blastoderm to move into close proximity to the eggshell, so that early embryonic mortality results from dehydration during the early stages of incubation (Brake et al., 1993).

According to Deeming (1995), day- old chick quality can be related to several factors, such as incubator quality, incubation environment, and egg characteristics. Although egg storage is a normal practice after egg collection and often a necessity in commercial incubation, it negatively influences egg quality and embryo development and results in a longer incubation time (Muambi et al., 1980). Furthermore, the spread of hatch can be influenced by the storage length of incubating eggs (Muambi et al., 1980; Christensen et al., 2001a), resulting in an increase in the number of chicks that experience delayed access to first feed (Decuypere et al., 2001). Because the end of $7 \mathrm{~d}$ of rearing is often considered as the true starting point for production, the performance (chick relative growth) of the chicks at this time may be an additional indication of chick quality. Chick relative growth rather than absolute weight gain measure the speed of growth in time and had previously been used to determine chick performance (Kühn et al., 1982).

In this paper, the influence of storage days on egg quality, the distribution for time of embryonic mortality during incubation, fertile hatchability and chick's viability at 14 days of age had been evaluated for Dandarawi chicken hatching eggs.

\section{MATERIALS AND METHODS}

\section{Experimental Design:}

This experiment was carried out at the Poultry Research Farm, Faculty of Agriculture, Assiut University, Assiut, Egypt. Hatching eggs were collected from 31 to 32 weeks of age Dandarawi hens. Eggs were collected 4 times daily for 15 consecutive days and stored at $16^{\circ} \mathrm{C}$ and $70 \% \mathrm{RH}$ until sorted into treatments and set into incubators. Any abnormal shaped eggs were eliminated. The eggs were incubated in a Petersime setter and hatcher. The setter was operated at $37.4 \pm 0.2^{\circ} \mathrm{C}$ dry-bulb temperature and $28.9 \pm 0.2^{\circ} \mathrm{C}$ wet-bulb temperature. The Hatcher was operated at $37.2 \pm 0.2^{\circ} \mathrm{C}$ dry-bulb temperature and $30.0 \pm 0.2^{\circ} \mathrm{C}$ wet-bulb temperatures. Eggs were turned once per hour through an angle of 90 from $\mathrm{d} 2$ to 18 of incubation and then they were transferred to the hatcher. The 15 experimental groups and control group were as follows: The fresh eggs as control incubated in the same day of lay (C), while eggs of one to fifteen treatments groups (G1 to G15) were stored from d 1 to 15 , respectively. Three replications of 80 eggs per group treatment per incubation setting (total of 3,840 eggs) were studied.

\section{Egg Quality:}

Thirty eggs were taken from each group. Egg weight was recorded to the nearest $0.1 \mathrm{~g}$ using special automatic balance and broken onto a flat surface where the height of the albumen was measured half way between the yolk and the edge of the inner thick albumen by a micrometer as described by Brant and Shrader (1952). The diameter of yolk was measured, using sliding caliber. The yolk was separated from the albumen and then yolk was weighted. Individual Haugh unit (Haugh, 1937) score was calculated using the egg weight and thick albumen height (Doyon et al., 1986), using the following formula: Haugh unit $=100 \log (\mathrm{H}-$ $\left.1.7 \mathrm{X} \mathrm{W} \mathrm{W}^{0.37}+7.6\right)$. Where: $\mathrm{H}=$ the observed height of the thick albumen in millimeters and $\mathrm{W}$ $=$ Weight of egg (grams). Also, the egg yolk index (EYI) was calculated by dividing the yolk's height X 100 /yolk's diameter.

\section{Hatching parameters:}

Eggs were individually weighed and labeled 
in order to identify the hatchlings with the eggs for each treatment (in pedigree baskets).. On d 6 and 12 of incubation, eggs were examined by candling to identify clear eggs and embryonic mortality. Eggs with embryonic development were considered fertile. After $510 \mathrm{~h}$ of incubation, the number of hatched chicks was recorded, weighed and it was expensed as percentage of egg weight, while all un-hatched eggs were opened to determine embryonic mortality from d 13 to 21 plus pipped. Fertile hatchability was calculated as the number of chicks hatched per fertile egg set. Embryonic mortality was calculated as a percentage of fertile eggs and divided into 4 categories: embryonic mortality from d 0 to 6 , from $\mathrm{d} 7$ to 12 , from d 13 to 21 , and pepping.

\section{Chick's viability:}

All of the hatched chicks were reared up to $14 \mathrm{~d}$ of age at 30 to $32^{\circ} \mathrm{C}$ on floor pens. The photoperiod was $24 \mathrm{hrs} /$ day during the first 3 days, which was gradually decreased by one $\mathrm{hr} /$ week, and a grower diet $(2,800 \mathrm{kcal}$ metabolizable energy and $18 \%$ crude protein) and water were provided ad libitum. The number of dead chicks was recorded daily and viability calculated of chicks.

\section{Statistical Analyses:}

The effect of storage duration was analyzed by one-way ANOVA with the general linear model (GLM) procedure (SAS Institute, 2004). Significance of differences among means was partitioned by the Duncan option (SAS Institute, 2004). Statements of statistical significance were based upon $\mathrm{P} \leq 0.05$.

\section{RESULTS AND DISCUSSION}

The results presented in Table 1 showed that during storage, the albumen height (AH), Haugh units (HU) and egg yolk index (EYI) decreased $(\mathrm{P} \leq 0.05)$ but the egg yolk percentage (EYP) increased $(\mathrm{P} \leq 0.05)$. These results are in agreement with those of many authors (Oosterwoud, 1987; Scott and Silversides, 2000; Silversides and Scott, 2001; Jones and Musgrove, 2005). Scott and Silversides (2000) reported that eggs from 31-wk-old ISA-White and ISA-Brown hens were sampled immediately after lay and after periods of storage of 1, 3, 5, and $10 \mathrm{~d}$ at room temperature. Longer periods of storage resulted in lower albumen weight and AH. Silversides and Scott (2001) found that during storage, albumen weight of eggs from ISA-White and ISA- Brown hens decreased and yolk weight increased slightly. Also, Jones and Musgrove (2005) revealed that, during storage, $\mathrm{AH}$ and HU decreased significantly $(\mathrm{P} \leq 0.01)$. The longer periods of storage resulted in higher EYP because the strength of the vitelline membrane decreased during storage due to the yolk absorbing water (Oosterwoud, 1987). Jones et al. (2002) reported that the elasticity of the vitelline membrane increased with egg age.

The results presented in Table 2 showed that the hatchability of eggs $(\mathrm{F})$ was lower $(\mathrm{P} \leq 0.05)$ with longer periods of storage, but the embryonic morality (EM) percentage increased $(\mathrm{P} \leq 0.05)$ during the periods from 0 to $6 \mathrm{~d}$ and from 13 to $21 \mathrm{~d}$ of incubation. The improvement in $\mathrm{F}$ in control seems to be due to the reduction in EM. El-Hammady et al. (2012) reported that normal hatchability of Dandarawi hens under production conditions were 78.0 and $65.3 \%$ in Autumn and winter, respectively. These results are in agreement with those found by Decuypere and Bruggeman (2007), Elibol and Brake (2008) and Reijrink et al. (2010) who found that hatchability decreased with increasing egg storage period as percentage early and late embryonic mortality increased. Prestorage incubation decreased embryonic mortality during the first $2 \mathrm{~d}$ of incubation, which was in agreement with Reijrink et al. (2009). Many investigators reported that egg storage longer significantly reduced F (Scott, 1933; Asmundson, 1947; Kosin, 1950; Merritt, 1964; Whitehead et al., 1985; Fasenko et al., 2001a,b) and increased EM (Merritt, 1964; Mather and Laughlin, 1976; Fasenko et al., 1992, 2001a, b; Brake et al., 1997; and Elibol et al., 2002) with increasing storage length. Lapã et al. (1999) suggest of that declines in hatchability with presetting storage start $1 \mathrm{~d}$ after lay, possibly due to deterioration in egg albumen quality. Each study suggests that the number of storage days before incubation might influence the distribution for time of embryonic mortality during incubation. There are two phases of increased embryonic mortality during incubation: the first phase occurs during the first week of incubation and the second phase during the last week (Payne, 1919; and Byerly, 1930).

Preincubational egg storage is known to affect general egg quality (yolk membranes, yolk, perivitelline layers). The incidence of more abnormal and dead embryos may be related to a higher number of embryonic cells with necrotic nuclei (Arora and Kosin, 1966b) and an increase in number of apoptotic cells (cells programmed to die) as a result of storage (Arora and Kosin, 1966a; and Mather and Laughlin, 1979). Bakst 
and Akuffo (1999) observed that a reduction of $32.8 \%$ in total number of turkey embryonic cells occurred during the first $2 \mathrm{~d}$ of storage. The initiation of embryonic development is delayed, which could be brought into relation with the delay in hatching time. This delay is seen in a later occurrence of the start of internal pipping (IP) and a prolonged IP stage (Tona et al., 2003). Moreover, the rate of embryonic development is slower due to longer storage, but this phenomenon is not observed for all embryos, indicating that not all embryos are affected by storage in the same way (Fasenko et al., 2002). Not only growth but also metabolism is found to be influenced by storage time. It has been shown that the metabolism of embryos, as measured indirectly by embryonic $\mathrm{CO} 2$ output, proceeds at a slower rate. Interestingly, Fasenko (1996) showed that turkey embryos from 14-d stored eggs relied more upon gluconeogenesis during pipping and hatching than embryos from 4-d stored eggs. Christensen et al., (2001b) showed that embryos from a line that resisted storage mortality maintained higher glycogen concentrations in muscle and heart tissues than those from a line susceptible to storage. The ability of the embryos to metabolize adequate carbohydrate reserves at time of hatching seems to be an advantage for embryonic growth and survival.

The results presented in Table 2 showed that day-old chick weights and chick weights at hatch as percentage of egg weights increased slightly when storage days increased. Silversides and Scott (2001) reported that, during storage of eggs from ISA-White and ISA-Brown hens, albumen weight decreased and yolk weight increased slightly. Yolk weight could be expected to increase with a longer period of storage as amino acids move through the vitelline membrane from the albumen (Heath, 1977). Fasenko (1996) demonstrated increased hepatic and renal gluconeogenic activities in turkey embryos from eggs that were stored prior to setting, compared to controls. In contrast, in the study of Reijrink et al. (2009), prestorage incubation (PSI) did not affect chick length on the day of hatch when egg storage was prolonged.

The control as well as G1 to G5 had no effect on viability of chicks at 14 days of age (VC), but $\mathrm{VC}$ was lower $(\mathrm{P} \leq 0.05)$ when storage days increased from 6 to $15 \mathrm{~d}$ (Table 2). Reijrink et al. (2010) reported that chick quality decreased when storage time increased. Tona et al. (2003, 2004) have shown that prolonged egg storage had a negative effect on chick quality in terms of physical parameters on the day of hatch, relative growth during the first $7 \mathrm{~d}$ of life, and weekly body weight until the slaughter age. Day-old chick quality is the result of events during embryonic development, and from the foregoing, it is clear that storage clearly affects embryonic development in different aspects (Decuypere and Bruggeman, 2007).

In general, storage period affected F, EM and VC. Our study suggests that incubation of Dandarawi eggs stored for longer periods decreases hatchability. Additional research is needed to define optimal incubation conditions to increase hatchability of Dandarawi eggs.

\section{ACKNOWLEDGMENTS}

Thanks are due to Prof. Dr. M.A. Abdelnabi, Animal and poultry production department, Assiut University, Assiut Egypt, for providing the birds.

\section{REFERENCES}

Arora, K.L., and I.L. Kosin, 1966a. Changes in the gross morphological appearance of chicken and turkey blastoderms during preincubation storage. Poultry Science 45:819-825.

Arora, K.L., and I.L. Kosin, 1966b. Developmental responses of early turkey and chicken embryos to preincubation holding of eggs: inter- and intra-species differences. Poultry Science 45:958-970.

Arora, K.L., and I.L. Kosin, 1968. The response of the early chicken embryo to pre-incubation temperature as evidenced from its gross morphology and mitotic pattern. Physiol. Zool. 41:104-112.

Asmundson, V.S., 1947. Time held prior to incubation and hatchability of turkey eggs. Poultry Science 26:305-307.

Bakst, M.R., and V. Akuffo, 1999. Impact of egg storage on embryonic development. Avian Poult. Biol. Rev. 13:125-131.

Becker, W.A., 1964. The storage of White Leghorn hatching eggs in plastic bags. Poultry Science 43:1109-1112.

Becker, W.A., J.V. Spencer, and J.L. Swartwood, 1968. Carbon dioxide during storage of chicken and turkey hatching eggs. Poultry Science 47:251-258.

Bloom, S.E., D.E. Muscarella, M. Y. Lee, and M. Rachlinski, 1998. Cell death in the avian blastoderm: Resistance to stress induced apoptosis and expression of anti-apoptotic genes. Cell Death Differ. 5:529-538.

Brake, J., T.J. Walsh, and S.V. Vick, 1993. Hatchability of broiler eggs as influenced by 
storage and internal quality. Zootech Int. 16(1):30-41.

Brake, J., T.J. Walsh, C.E. Benton, Jr., J.N. Petitte, R. Meijerhof, and G. Pen alva, 1997. Egg handling and storage. Poultry Science 76:144151.

Brant, A.W., and H.L. Shrader, 1952. How to measure internal egg quality? Bureau of Animal Industry, Agric. Res. Administration, U.S. Dept. of Agric., Circular P.A. 202.

Burley, R.W., and D.V. Vadehra, 1989. The Avian Egg: Chemistry and Biology. John Wiley and Sons, New York, NY.

Byerly, T.C., 1930. Time of occurrence and probable causes of mortality in chick embryos. Pages 178-186 in: Report of Proceedings of the ${ }^{4}$ th World's Poultry Congress. H. M. Sta- tionary Office, London, UK.

Byng, A.L., and D. Nash, 1962. The effects of egg storage on hatchability. British Poultry Science 3:81-87.

Christensen, V.L., J.L. Grimes, and M.J. Wineland, 2001a. Effects of turkey breeder hen age, strain, and length of the incubation period on survival of embryos and hatchlings. J. Appl. Poult. Res. 10:5-15.

Christensen, V.L., M.J. Wineland, G.M. Fasenko, and W.E. Donaldson, 2001b. Egg storage effects on plasma glucose and supply and demand tissue glycogen concentrations of broiler embryos. Poultry Science 80:1729-1735.

Decuypere, E., and V. Bruggeman, 2007. The endocrine interface of environmental and egg factors affecting chick quality. Poultry Science 86:1037-1042.

Decuypere, E., K. Tona, V. Bruggeman, and F. Bamelis, 2001. The day-old chick, a crucial hinge between breeders and broilers. World's Poultry Science J. 57:127-138.

Deeming, D.C., 1995. What is chick quality? World's Poultry Science Journal 11:20-23.

Doyon, G., M. Bernier-Cardou, R.M.G. Hamilton, F. Eastaigns, and C.T. Ramdald, 1986. Egg quality. 2. Albumen quality of egg from five commercial strains of White Leghorn hens during one year of lay. Poultry Science 65: 6366.

Duncan, D.B., 1955. Multiple range and multiple F tests. Biometrics, 11:1-42.

El-Hammady, H.Y., M. El-Sagheer, and M.F.A. Farghly 2012. Effect of the time of feeding on the productive and reproductive performance of Danadarawi chicken under the prevailing subtropical climatic conditions in Assiut. Egyptian J. of Anim. Prod. 49 (I): 67-76.

Elibol, O. and J. Brake, 2008. Effect of egg position during three and fourteen days of storage and turning frequency during subsequent incubation on hatchability of broiler hatching eggs. Poultry Science 87:1237-1241.

Elibol, O., S.D. Peak and J. Brake, 2002. Effect of flock age, length of egg storage, and frequency of turning during storage on hatchability of broiler hatching eggs. Poultry Science 81:945950.

Fasenko, G.M., 1996. Factors influencing embryo and poultry viability and growth during long term storage of turkey eggs. Ph.D. Thesis. North Carolina State Univ., Raleigh.

Fasenko, G.M., F.E. Robinson, A. I. Whelan, K. M. Kremeniuk, and J.A. Walker, 2001b. Prestorage incubation of long-term stored broiler breeder eggs:1. Effects on hatchability. Poultry Science 80:1406-1411.

Fasenko, G.M., F.E. Robinson, and R.T. Harden, 1992. Variability in pre-incubation embryonic development in domestic fowl. 2. Effects of duration of egg storage period. Poultry Science 71:2129-2132.

Fasenko, G.M., F.E. Robinson, J.C. Segura, J.J.R. Feddes, and C.A. Ouellette, 2002. Long term hatching egg storage alters the metabolism of broiler embryos. Poultry Science 80 (Suppl.1):62.

Fasenko,G.M., V.L. Christensen, M.J. Wineland, and J.N. Petitte, 2001a. Examining the effects of prestorage incubation of turkey breeder eggs on embryonic development and hatchability of eggs stored for four or fourteen days. Poultry Science 80:132-138.

Fromm, D., 1966. The influence of ambient $\mathrm{pH}$ on moisture content and yolk index of the hen's yolk. Poultry Science 45:374-379.

Haugh, R.R., 1937. The Haugh unit for measuring egg quality. U.S. Egg. Poult. Mag. 43: 522-555 and $572-573$.

Heath, J.L., 1977. Chemical and related osmotic changes in egg albumen during storage. Poultry Science 56:822-828.

Jones, D.R., and M.T. Musgrove, 2005. Effects of extended storage on egg quality factors. Poultry Science 84:1774-1777.

Jones, D.R., J.B. Tharrington, P.A. Curtis, K.E. Anderson, K.M. Keener, and F.T. Jones, 2002. Effects of cryogenic cooling of shell eggs on egg quality. Poultry Science 81:727-733.

Kahraman-Dogan, H., L. Bayindirli, and $M$. Ozilgen, 1994. Quality control charts for storage of eggs. Food Qual. 17:495-501.

Kosin, I.L., 1950. A relationship between the length of storage and incubation periods in Broad Breasted Bronze eggs. Poultry Science 29:620621.

Ku“hn, E.R., E. Decuypere, L.M. Colen, and H. 
Michels, 1982. Posthatch growth and development of a circadian rhythm for thyroid hormones in chicks incubated at different temperatures. Poultry Science 61:540-549.

Lapa , O., C., L.T. Gama, and M. Chaveiro Soares, 1999. Effects of broiler breeder age and length of egg storage on albumen characteristics and hatchability. Poultry Science 78:640-645.

Mather, C.M., and K.F. Laughlin, 1976. Storage of hatching eggs: the effect on total incubation period. British Poultry Science 17:471-479.

_Mather, C.M., and K.F. Laughlin, 1979. Storage of hatching eggs: the interaction between parental age and early embryonic development. British Poultry Science 20:595604.

Meijerhof, R., 1992. Pre-Incubation holding of hatching eggs. World's Poultry Science Journal 48:57-68.

Merritt, E.S., 1964. Pre-incubation storage effects on subsequent performance of chickens. Br. Poultry Science 5:67-73.

Meuer, H.J., and R. Baumann, 1988. Oxygen pressure in intra-and extraembryonic blood vessels of early chick embryo. Resp. Physiol. 71:331-342

Muambi, S., E. Decuypere, and H. Michel, 1980. Influence de la duré e de conservation des oeufs sur la durée d'incubation, le taux d'éclosion et la croissance postnatale chez la race de volaille "Rhode Island Red." Rev. Zaïr. Sci. Nucl. $1(2): 65-83$.

Oosterwoud, A., 1987. Effect of egg handling on egg quality. Poultry Science Symp. 20:283-291.

Payne, L.F., 1919. Distribution of mortality during the period of incubation. J. Am. Assoc. Instr. Invest. Poult. Husb. 6:9-12.

Reijrink, I.A.M., R. Meijerhof, B. Kemp, E.A.M. Graat, and H. van den Brand, 2009. Influence of prestorage incubation on embryonic development, hatchability, and chick quality. Poultry Science 88:2649-2660.

Reijrink, I.A.M., D. Berghmans, R. Meijerhof, B. Kemp, and $H$. van den Brand, 2010. Influence of egg storage time and preincubation warming profile on embryonic development, hatchability, and chick quality. Poultry Science 89:1225-1238.

Reijrink, I.A.M., R. Meijerhof, B. Kemp, and H. van den Brand, 2008. The chicken embryo and its micro environment during egg storage and early incubation. World's Poultry Science Journal 64:581-598.

SAS Institute, 2004. SAS/STAT User's Guide. Version 9.1. SAS Institute Inc., Cary, NC.
Scott, H.M., 1933. The effect of age and holding temperature on hatchability of turkey and chicken eggs. Poultry Science 12:49-54.

Scott, T.A., and F.G. Silversides, 2000. The effect of storage and strain of hen on egg quality. Poultry Science 79:1725-1729.

Scott, T.A., and C.J. Mackenzie, 1993. Incidence and classification of early embryonic mortality in broiler breeder chickens. British Poultry Science 34:459-470.

Shenstone, F.S., 1968. The gross composition, chemistry and physico-chemical basis of organization of the yolk and white. Pages 26-58 in Egg Quality: A Study of the Hen's Egg. T. C. Carter, ed. Oliver and Boyd, Edinburgh, UK.

Silversides, F.G., and T.A. Scott, 2001. Effect of storage and layer age on quality of eggs from two lines of hens. Poultry Science 80:12401245.

Silversides, F.G. and P. Villeneuve, 1994. Is the Haugh unit correction for egg weight valid for eggs stored at room temperature? Poultry Science 73:50-55.

Stern, C.D., 1991. The sub-embryonic fluid of the egg of the domestic fowl and its relationship to the early development of the embryo. Pages 81-90 in: Avian Incubation. S. G. Tullett, ed. Butterworth-Heinemann, London, U.K.

Tona, K., O. Onagbesan, B. De Ketelaere, E. Decuypere, and V. Bruggeman, 2004. Effects of age of broiler breeders and egg storage on egg quality, hatchability, chick quality, chick weight and chick post-hatch growth to 42 days. J. Appl. Poult. Res. 13:10-18.

Tona, K., R.D. Malheiros, F. Bamelis, C. Careghi, V. Bruggeman, V.M. Moraes, O. Onagbesan, and E. Decuypere, 2003. Effects of storage time on incubating egg gas pressure, thyroid hormones and corticosterone levels in embryos, and their hatching parameters. Poultry Science 82:840845.

Whitehead, C.C., M.H. Maxwell, R.A. Pearson, and K.M. Herron, 1985. Influence of egg storage on hatchability, embryonic development and vitamin status in hatching broiler chicks. British Poultry Science 26:221-228.

Yassin, H., A.G.J. Velthuis, M. Boerjan, J. van Riel, and R.B.M. Huirne, 2008. Field study on broiler eggs hatchability. Poultry Science 87:24082417.

Yoo, B.H., and E. Wientjes, 1991. Rate of decline in hatchability with preincubation storage of chicken eggs depends on genetic strain. British Poultry Science 32:733-740. 
Table 1. Effect of eggs storage days on egg quality ( $n=30$ eggs)

\begin{tabular}{|c|c|c|c|c|c|}
\hline $\begin{array}{l}\text { Items } \\
\text { Treat }\end{array}$ & $\begin{array}{c}\text { Egg weight } \\
\text { (g) }\end{array}$ & $\begin{array}{c}\text { Albumen height } \\
(\mathrm{mm})\end{array}$ & $\begin{array}{c}\text { Haugh Units } \\
(\mathrm{mm})\end{array}$ & $\begin{array}{c}\text { Egg yolk index } \\
(\%)\end{array}$ & $\begin{array}{c}\text { Egg yolk } \\
(\%) \\
\end{array}$ \\
\hline Go & $47.4 \pm 0.31$ & $8.13^{\mathrm{a}} \pm 0.31$ & $92.55^{\mathrm{a}} \pm 1.65$ & $58.52^{\mathrm{a}} \pm 0.73$ & $32.61^{\mathrm{g}}$ \\
\hline G1 & $47.5 \pm 0.32$ & $6.97^{b} \pm 0.24$ & $86.23^{\mathrm{b}} \pm 1.43$ & $56.05^{\mathrm{a}} \pm 0.87$ & $33.69^{\mathrm{g}}$ \\
\hline G2 & $47.3 \pm 0.29$ & $5.56^{\mathrm{c}} \pm 0.23$ & $76.97^{\mathrm{c}} \pm 1.74$ & $53.11^{\mathrm{b}} \pm 0.79$ & $34.13^{\mathrm{efg}}$ \\
\hline G3 & $47.1 \pm 0.28$ & $5.31^{\mathrm{cd}} \pm 0.22$ & $75.55^{\mathrm{c}} \pm 1.57$ & $53.15^{\mathrm{b}} \pm 0.98$ & $34.34^{\mathrm{efg}}$ \\
\hline G4 & $47.6 \pm 0.33$ & $4.97^{\mathrm{cde}} \pm 0.28$ & $72.31^{\mathrm{cd}} \pm 2.28$ & $51.11^{\mathrm{bc}} \pm 1.07$ & $34.65^{\mathrm{def}}$ \\
\hline G5 & $47.6 \pm 0.34$ & $4.83^{\mathrm{def}} \pm 0.29$ & $71.82^{\text {cde }} \pm 2.08$ & $49.39^{\mathrm{cd}} \pm 0.71$ & $34.78^{\text {cdef }} \pm 0.62$ \\
\hline G6 & $47.0 \pm 0.36$ & $4.54^{\mathrm{efg}} \pm 0.15$ & $68.85^{\mathrm{def}} \pm 1.41$ & $48.49^{\mathrm{de}} \pm 0.95$ & $34.91^{\text {cdef }} \pm 0.53$ \\
\hline G7 & $47.4 \pm 0.37$ & $4.27^{\mathrm{efg}} \pm 0.19$ & $67.67^{\mathrm{defg}_{ \pm}} \pm 1.72$ & $48.30^{\mathrm{de}} \pm 1.04$ & $34.92^{\text {cdef }} \pm 0.72$ \\
\hline G8 & $47.5 \pm 0.38$ & $4.25^{\mathrm{fgh}} \pm 0.23$ & $67.0^{\text {defgh }} \pm 2.09$ & $47.59^{\mathrm{def}} \pm 0.80$ & $35.33^{\text {bcdef }} \pm 0.64$ \\
\hline G9 & $47.4 \pm 0.28$ & $4.15^{\mathrm{fgh}} \pm 0.17$ & $65.88^{\text {eghf }} \pm 1.93$ & $46.42^{\mathrm{efg}} \pm 0.73$ & $35.55^{\text {abcdef }} \pm 0.63$ \\
\hline G10 & $47.7 \pm 0.29$ & $3.99^{\text {fgh }} \pm 0.19$ & $64.88^{\mathrm{ghf}} \pm 1.65$ & $46.17^{\text {efg }} \pm 0.60$ & $35.65^{\text {abcde }} \pm 0.61$ \\
\hline G11 & $47.6 \pm 0.39$ & $3.89^{\mathrm{ghi}} \pm 0.18$ & $63.85^{\mathrm{fgh}} \pm 1.98$ & $46.07^{\text {efg }} \pm 1.15$ & $36.35^{\mathrm{abcd}} \pm 0.52$ \\
\hline G12 & $47.8 \pm 0.28$ & $3.79^{\mathrm{hi}} \pm 0.18$ & $62.42^{\mathrm{ghi}} \pm 1.79$ & $45.87^{\mathrm{efg}} \pm 1.10$ & $36.57^{\mathrm{abc}} \pm 0.56$ \\
\hline G13 & $47.3 \pm 0.25$ & $3.75^{\mathrm{hi}} \pm 0.26$ & $61.69^{\mathrm{ghi}} \pm 2.78$ & $45.25^{\mathrm{fg}} \pm 0.73$ & $36.88^{\mathrm{ab}}$ \\
\hline G14 & $47.8 \pm 0.24$ & $3.74^{\mathrm{hi}} \pm 0.25$ & $60.87^{\mathrm{hi}} \pm 2.60$ & $44.42^{\mathrm{g}} \pm 0.91$ & $36.95^{\mathrm{ab}}$ \\
\hline G15 & $475 \pm 0.26$ & $3.32^{\mathrm{i}} \pm 0.15$ & $57.15^{\mathrm{i}} \pm 1.85$ & $44.12^{\mathrm{g}} \pm 0.92$ & $37.23^{\mathrm{a}}$ \\
\hline
\end{tabular}

${ }^{\mathrm{a}-\mathrm{i}}$ Means $\pm \mathrm{SE}$ within each column with different superscripts are significantly different $(\mathrm{P} \leq 0.05)$.

Go to $\mathrm{G} 15$ = the eggs were stored from d 0 to 15 , respectively.

Table 2. Effect of eggs storage days on fertile hatchability (FH), embryo mortality (EM), egg weight (EW), day -old chick weights (DCW), chick weights at hatch as percentage of egg weights (DCWP) and viability of chicks (VC)

\begin{tabular}{|c|c|c|c|c|c|c|c|c|}
\hline \multirow[b]{2}{*}{$\begin{array}{l}\text { Items } \\
\text { Treat }\end{array}$} & \multirow[b]{2}{*}{ FH (\%) } & \multicolumn{4}{|c|}{ EM (\%) } & \multirow[b]{2}{*}{ DCW (g) } & \multirow[b]{2}{*}{ DCWP (\%) } & \multirow[b]{2}{*}{ VC (\%) } \\
\hline & & $\begin{array}{l}0 \text { to } 6 \mathrm{~d} \text { of } \\
\text { incubation }\end{array}$ & $\begin{array}{l}7 \text { to } 12 \text { d of } \\
\text { incubation }\end{array}$ & $\begin{array}{l}13 \text { to } 21 \mathrm{~d} \\
\text { of } \\
\text { incubation }\end{array}$ & Pipping & & & \\
\hline Go & $74.07^{\mathrm{a}} \pm 0.96$ & $0.79^{\mathrm{h}} \pm 0.10$ & $2.38^{\mathrm{de}} \pm 0.46$ & $16.67^{\mathrm{g}} \pm 0.46$ & $6.09^{\mathrm{fg}} \pm 0.53$ & $27.68^{\mathrm{c}} \pm 0.20$ & $57.70^{b} \pm 0.53$ & $98.89^{\mathrm{a}} \pm 0.64$ \\
\hline G1 & $71.88^{\mathrm{b}} \pm 0.90$ & $0.78^{\mathrm{h}} \pm 0.10$ & $2.34^{\mathrm{de}} \pm 0.45$ & $17.97^{\mathrm{fg}} \pm 0.47$ & $7.03^{\mathrm{ef}} \pm 0.90$ & $27.11^{\mathrm{c}} \pm 0.19$ & $57.77^{b} \pm 0.54$ & $98.68^{\mathrm{a}} \pm 0.76$ \\
\hline G2 & $71.47^{\mathrm{b}} \pm 0.71$ & $3.20^{\mathrm{g}} \pm 0.46$ & $1.60^{\mathrm{e}} \pm 0.42$ & $18.67^{\mathrm{f}} \pm 0.27$ & $4.80^{\mathrm{g}} \pm 0.46$ & $27.11^{\mathrm{c}} \pm 0.25$ & $57.93^{b} \pm 0.65$ & $98.68^{\mathrm{a}} \pm 0.76$ \\
\hline G3 & $66.41^{\mathrm{c}} \pm 0.12$ & $3.91^{\mathrm{g}} \pm 0.45$ & $3.91^{\mathrm{abc}} \pm 0.41$ & $17.97^{\mathrm{fg}} \pm 0.44$ & $7.81^{\mathrm{de}^{\mathrm{e}}} \pm 0.90$ & $27.28^{\mathrm{c}} \pm 0.23$ & $58.10^{\mathrm{b}} \pm 0.71$ & $98.31^{\mathrm{a}} \pm 0.98$ \\
\hline G4 & $62.30^{\mathrm{d}} \pm 0.17$ & $5.74^{\mathrm{f}} \pm 0.47$ & $4.10^{\mathrm{abc}} \pm 0.40$ & $19.12^{\mathrm{f}} \pm 0.47$ & $8.75^{\text {bcde }} \pm 0.27$ & $27.29^{\mathrm{bc}} \pm 0.28$ & $58.29^{\mathrm{ab}} \pm 0.70$ & $97.30^{\mathrm{a}} \pm 0.80$ \\
\hline G5 & $59.84^{\mathrm{e}} \pm 0.45$ & $6.30^{\mathrm{f}} \pm 0.45$ & $3.94^{\mathrm{abc}} \pm 0.44$ & $22.83^{\mathrm{e}} \pm 0.43$ & $7.09^{\mathrm{ef}} \pm 0.45$ & $27.29^{b c} \pm 0.23$ & $58.31^{\mathrm{ab}} \pm 0.63$ & $96.55^{\mathrm{abc}} \pm 1.00$ \\
\hline G6 & $59.68^{\mathrm{e}} \pm 0.93$ & $9.68^{\mathrm{e}} \pm 0.46$ & $4.03^{\mathrm{abc}} \pm 0.45$ & $17.74^{\mathrm{fg}} \pm 0.42$ & $8.87^{\text {bcd }} \pm 0.47$ & $27.34^{b c} \pm 0.25$ & $58.54^{\mathrm{ab}} \pm 0.67$ & $94.60^{\text {bcd }} \pm 0.78$ \\
\hline G7 & $58.79^{\mathrm{e}} \pm 0.52$ & $10.24^{\mathrm{e}} \pm 0.45$ & $3.94^{\mathrm{abc}} \pm 0.41$ & $16.80^{\mathrm{g}} \pm 0.40$ & $10.24^{\mathrm{b}} \pm 0.44$ & $27.38^{b c} \pm 0.28$ & $58.60^{\mathrm{ab}} \pm 0.63$ & $94.32^{\text {bcde }} \pm 0.66$ \\
\hline G8 & $57.97^{\mathrm{e}} \pm 1.41$ & $10.32^{\mathrm{e}} \pm 0.42$ & $3.97^{\mathrm{abc}} \pm 0.41$ & $17.72^{\mathrm{fg}} \pm 0.26$ & $10.05^{\mathrm{b}} \pm 0.27$ & $27.45^{\mathrm{bc}} \pm 0.29$ & $58.62^{\mathrm{ab}} \pm 0.73$ & $93.41^{\text {cdef }} \pm 0.64$ \\
\hline G9 & $52.85^{\mathrm{f}} \pm 1.41$ & $10.57^{\mathrm{de}} \pm 0.47$ & $4.07^{\mathrm{abc}} \pm 0.47$ & $22.76^{\mathrm{e}} \pm 0.47$ & $9.76^{\mathrm{bc}} \pm 0.47$ & $27.51^{b c} \pm 0.35$ & $58.64^{\mathrm{ab}} \pm 0.90$ & $93.55^{\text {cdefg }} \pm 1.86$ \\
\hline G10 & $47.72^{\mathrm{g}} \pm 0.20$ & $10.48^{\mathrm{de}} \pm 0.45$ & $5.11^{\mathrm{a}} \pm 0.27$ & $29.30^{c} \pm 0.27$ & $8.06^{\mathrm{cde}} \pm 0.46$ & $27.71^{\mathrm{bc}} \pm 0.27$ & $59.49^{\mathrm{ab}} \pm 0.74$ & $92.55^{\text {defgh }} \pm 0.62$ \\
\hline G11 & $46.72^{\mathrm{g}} \pm 0.26$ & $11.02^{\mathrm{de}} \pm 0.46$ & $4.98^{\mathrm{a}} \pm 0.46$ & $27.56^{\mathrm{d}} \pm 0.26$ & $9.97^{\mathrm{b}} \pm 0.52$ & $27.72^{\mathrm{bc}} \pm 0.33$ & $59.56^{\mathrm{ab}} \pm 0.97$ & $90.74^{\text {efgh }} \pm 1.07$ \\
\hline G12 & $42.52^{\mathrm{h}} \pm 0.46$ & $11.81^{\mathrm{d}} \pm 0.47$ & $4.72^{\mathrm{ab}} \pm 0.41$ & $32.28^{\mathrm{b}} \pm 0.46$ & $8.66^{\text {bcde }} \pm 0.46$ & $27.96^{\mathrm{abc}} \pm 0.34$ & $59.82^{\mathrm{ab}} \pm 0.86$ & $90.00^{\mathrm{fgh}} \pm 1.92$ \\
\hline G13 & $39.37^{\mathrm{i}} \pm 0.46$ & $15.72^{c} \pm 0.41$ & $4.72^{\mathrm{ab}} \pm 0.40$ & $31.50^{\mathrm{b}} \pm 0.47$ & $8.66^{\text {bcde }} \pm 0.45$ & $28.13^{\mathrm{ab}} \pm 0.48$ & $60.04^{\mathrm{ab}} \pm 1.28$ & $89.86^{\mathrm{gh}} \pm 0.83$ \\
\hline G14 & $21.55^{\mathrm{j}} \pm 0.50$ & $18.97^{\mathrm{b}} \pm 0.50$ & $3.45^{\mathrm{abc}} \pm 0.50$ & $43.97^{\mathrm{a}} \pm 0.50$ & $12.07^{\mathrm{a}} \pm 0.51$ & $28.18^{\mathrm{ab}} \pm 0.35$ & $60.09^{\mathrm{a}} \pm 0.87$ & $89.29^{\mathrm{h}} \pm 2.0$ \\
\hline G15 & $15.69^{\mathrm{k}} \pm 0.74$ & $24.37^{\mathrm{a}} \pm 0.49$ & $3.08^{\mathrm{cd}} \pm 0.28$ & $42.86^{\mathrm{a}} \pm 0.49$ & $13.45^{\mathrm{a}} \pm 0.48$ & $28.74^{\mathrm{a}} \pm 0.47$ & $61.27^{\mathrm{a}} \pm 1.18$ & $80.39^{\mathrm{i}} \pm 1.13$ \\
\hline
\end{tabular}




\section{تأثير طول فترة تخزين البيض قبل التفريخ على نسبة الفقس والنفوق الجنيني وحيوية الكتاكيت محمد الصغير محمد حسن فيز نغن}

\section{قسم الإنتاج الحيواني والدواجن، كلية الزراعة، جامعة أسيوط، 4 ب ا V أسيوط، مصر}

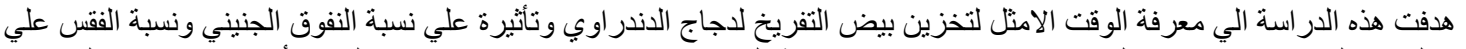

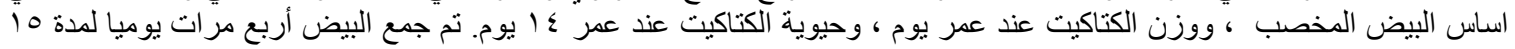

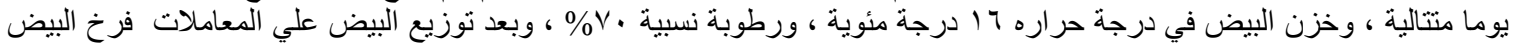

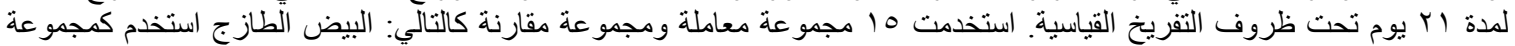

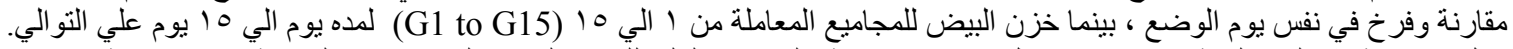

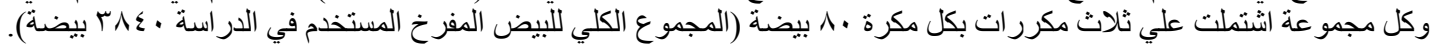

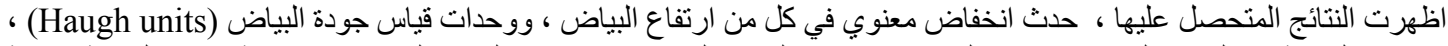

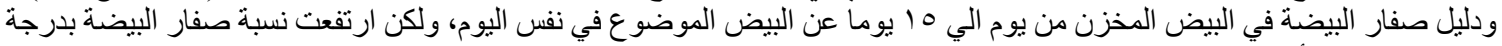

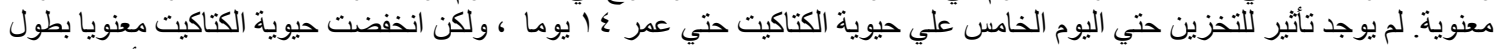

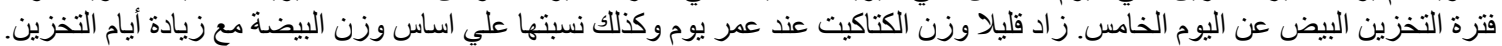

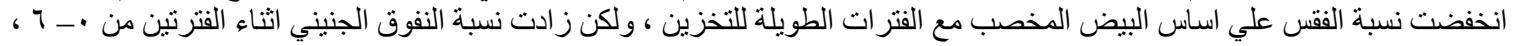

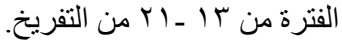
ومن النتائج السابقة توضح انخفاض نسبة الفقس مع تخزين البيض بداية من اليوم الاول بعد وضع البيض ، ويرجع سبب ذلك الي تدهور في جودة البيض اثناء التخزين. 